\title{
Photo-induced antimicrobial and DNA cleavage studies of indoloquinolines and 1,8-naphtharidine
}

\author{
MALATHI MAHALINGAM ${ }^{\mathrm{a}, \uparrow, *}$, PALATHURAI SUBRAMANIAM MOHAN ${ }^{\mathrm{a}}$, \\ KASIRAJAN GAYATHRI ${ }^{\mathrm{a}}$, RAMADOSS GOMATHI ${ }^{\mathrm{a}, \#}$ and PUSHPARAJA SUBHAPRIYA ${ }^{\mathrm{b}}$ \\ ${ }^{a}$ Department of Chemistry, Bharathiar University, Coimbatore 641 046, India \\ ${ }^{\mathrm{b}}$ Department of Chemistry, Bannari Amman Institute of Technology, Sathyamangalam 638 401, India \\ †Present address: Department of Chemistry, Bannari Amman Institute of Technology, Sathyamangalam, India \\ \#Present address: Department of Inorganic Chemistry, Madurai Kamarajar University, Madurai, India \\ e-mail: malathichem@gmail.com
}

MS received 12 December 2012; revised 12 April 2013; accepted 17 May 2013

\begin{abstract}
Angular and linear isomers of indoloquinoline are synthesized from 4-hydroxyquinolin-2(1H)-one. The use of Vilsmeier-Haack reagent on $N$-phenylpropionamide yielded a new versatile method for the synthesis of 2-chloro-3-methylquinoline which is utilized as precursor in the synthesis of basic camptothecin core and quinoline fused with 1,8-naphthridine. The in vivo photoinduced antibacterial activity of all the synthesized compounds has been studied. The unique photo-bioactivity of $5 H$-indolo[3,2-c]quinolin-6(11H)-one is further studied under the photo-DNA cleavage analysis. Theoretical calculations for the synthesized compounds are performed to determine further credentials of the biological results.
\end{abstract}

Keywords. Vilsmeier-Haack reagent; indoloquinolines; photosensitizer; photoinduced antibacterial activity; photo-DNA binding.

\section{Introduction}

The wide range of physical and chemical properties of quinoline derivatives has led to their successful use in different fields either in biology or material chemistry. ${ }^{1}$ Such derivatives having fused heterocyclics or an extended $\pi$ conjugation of molecular orbitals specifically facilitate facile electron exchange ability in the excited electronic state and cause significant absorption in the visible region. ${ }^{2}$ This potential photochemical activity has been investigated in the field of photobiology as photosensitizer.

In general, quinolines and their derivatives are known to exhibit interesting optical properties. ${ }^{3}$ Several studies have explored the wide applicability of quinoline compounds in photo-bioanalytical, ${ }^{4}$ photo-biological ${ }^{5}$ and also opto electronics ${ }^{6}$ besides well-known usage in the field of pharmacology. Gordon Fels ${ }^{7}$ has studied the photo-bioactivity of quinoline compounds and concluded that heterocyclic nitrogen could act as the photochemical centre. Rothe and Jacobus ${ }^{8}$ extended the study in order to illustrate the substitutional effects in the

*For correspondence photo-bioactivity of quinoline derivatives. It explored the view that steric hindrance at the quinoline's second position decreases its phototoxic potency, but electronegative functional groups in its fourth position increases its phototoxic potency. Significantly, Mallick and Chattopadhgay ${ }^{9}$ had illustrated that the extent of photodynamic action did not depend only on the singlet oxygen producing ability but also on the biodistribution of the photosensitizer molecule in the cytoplasmic and mitrochondrial membranes, their retention and the nature of binding inside the cell. It illustrated that the photo-bioactivity of a compound is influenced by molecular micropolarity.

Considerable interest in the synthesis of indoloquinoline analogues has been shown by several research groups due to the broad spectrum of its biological activities. ${ }^{10,11}$ It is important to note that biological activity of the derivatives and the mechanism of its metabolism in living systems are eventually connected to their DNA intercalation. ${ }^{12-14}$ The consequences of DNA intercalation by exogenous molecules have attracted considerable interest in photo-medicinal chemistry because it could hinder or suppress the function of nucleic acid in physiological processes. ${ }^{15}$ Exploration of such studies becomes significant if the DNA-targeted molecules are also photosensitizers of the nucleic acid cleavage. ${ }^{16}$ 


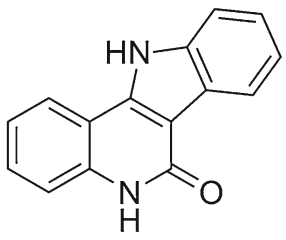

1

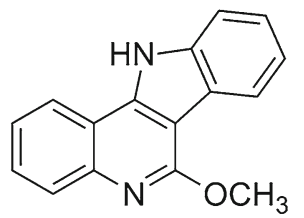

2<smiles>COc1c2ccccc2nc2[nH]c3ccccc3c12</smiles>

3

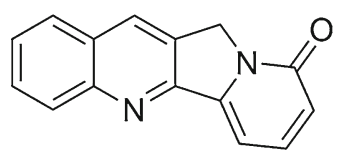

4<smiles>c1cnc2c(c1)CNc1ncccc1-2</smiles>

5

Scheme 1. Quinoline ring systems used for photo-bioactivity.

Accordingly, the photosensitization of cells and tissues using photo-bioactive drugs have been exploited in a variety of photoinduced therapies against microbes ${ }^{17}$ and cancer cells. ${ }^{18}$

Emergence of antibiotic resistance among pathogenic bacteria has led to a major research effort to find alternative antibacterial therapies. ${ }^{19}$ Bacterial photodynamic inactivation (PDI) is based on the administration of a photosensitizer, which is preferentially accumulated in the microbial cells. Subsequent irradiation with visible light, in the presence of oxygen, specifically produces cell damage that inactivates the microorganisms. ${ }^{20}$ Different oxidative mechanisms can be proposed for photo bio-activation of photosensitizers on microbes. In type I photochemical reaction, the photosensitizer interacts with a biomolecule to produce free radicals, while in type II mechanism, singlet molecular oxygen, $\mathrm{O}_{2}\left({ }^{1} \Delta \mathrm{g}\right)$, is produced as the main species responsible for cell inactivation. ${ }^{21}$ Quinoline derivatives could produce quinoline radical anion (Q--) during the excitation and initiate superoxide $\left(\mathrm{O}_{2} \cdot-\right)$ formation through electron-transfer pathway. ${ }^{22}$ In addition, it was reported that the photosensitizers containing cationic groups produce direct photoinactivation of Gram negative bacteria even in the absence of additives. ${ }^{23}$ On the basis of these considerations, we are interested in focusing on the synthesis and photo-bioactivity analysis of heterocyclic ring fused quinoline derivatives.

Here, we are reporting potent quinoline intermediates for the synthesis of indolo and naphtharidine ring fused quinoline derivatives (scheme 1) and their photobioactivity against bacteria upon UV irradiation. The choice of these structures is in accordance with the fact that the micropolarity around the molecule plays a significant part in the photo-bioactivity and hence it is of pharmacological interest to study and incorporate the photo-bioactivity of different ring systems fused with quinoline derivatives.

\section{Experimental}

\subsection{Chemistry}

All the solvents were of analytical grade purity and dry. Thin-layer chromatography (TLC) was performed using glass plates coated with silica gel-G containing $13 \%$ calcium sulphate binder. Melting points were determined on Boetieus Microheating table or Mettler FP5 apparatus and were uncorrected. IR spectra were recorded on a fourier transform infrared spectroscopy (FTIR) Perkin Elmer 537 spectrometer using $\mathrm{KBr}$ disc or Nujol mull and the absorption frequencies were expressed in reciprocal centimetres $\left(\mathrm{cm}^{-1}\right)$. ${ }^{1} \mathrm{H}$ and ${ }^{13} \mathrm{C}$ nuclear magnetic resonance (NMR) spectra were recorded on Bruker- $400 \mathrm{MHz}$ spectrometer and chemical shifts $(\delta)$ in ppm were referred to tetramethylsilane (TMS). Solvent systems were petroleum ether/ethyl acetate, trichloromethane/methanol. Spots were visualized by shortwave UV light and iodine vapour. Column chromatography was performed on silica gel (80-120 mesh).

2.1a Synthesis of 4-hydroxyquinolin-2(1H)-one $(\mathbf{6})^{24}$ : White solid $(12.47 \mathrm{~g}, 99 \%)$. $\mathrm{mp} 352^{\circ} \mathrm{C}$; IR (KBr) 2500 3415 (bb), $1695 \mathrm{~cm}^{-1} ;{ }^{1} \mathrm{H}$ NMR (DMSO, $\left.500 \mathrm{MHz}\right) \delta$ $5.75(\mathrm{~s}, 1 \mathrm{H}), 7.15(\mathrm{t}, 1 \mathrm{H}, J=8 \mathrm{~Hz}), 7.26(\mathrm{~d}, 1 \mathrm{H}$, $J=8 \mathrm{~Hz}), 7.49(\mathrm{t}, 1 \mathrm{H}, J=8 \mathrm{~Hz}), 7.78(\mathrm{~d}, 1 \mathrm{H}$, $J=8 \mathrm{~Hz}), 11.22(\mathrm{~s}, 1 \mathrm{H}), 12.6(\mathrm{bs}, 1 \mathrm{H}) ;{ }^{13} \mathrm{C} \mathrm{NMR}$ (DMSO) $\delta 101.22,117,72,119.47,123.54,124.02$, $128.95,137.63,160.57,161.84$. The $\mathrm{C}, \mathrm{H}$ and $\mathrm{N}$ contents were determined by elemental analysis (Anal. Calcd. for $\mathrm{C}_{9} \mathrm{H}_{7} \mathrm{NO}_{2}$ (\%) C 67.08, H 4.38, N 8.69; found C 66.79, H 4.09, N 8.52).

2.1b Synthesis of 2,4-dichloroquinoline (7): 4-Hydroxyquinolin-2(1H)-one $(526 \mathrm{mg}, 3.26 \mathrm{mmol})$ was refluxed by stirring in phosphoryl chloride $(5 \mathrm{~mL})$ for 
$3 \mathrm{~h}$. The mixture was cooled, poured into crushed ice with vigorous stirring and neutralized with saturated $\mathrm{NaHCO}_{3}$. The resulting brown crude was filtered and dried. The white needle product $(431 \mathrm{mg}$, $66.67 \%$ ) was isolated from the crude through column chromatography using petroleum ether as eluent $(0 \%)$. $\mathrm{mp} 76^{\circ} \mathrm{C}$; IR (KBr) 1583, 1030, $748 \mathrm{~cm}^{-1} ;{ }^{1} \mathrm{H}$ NMR $\left(\mathrm{CDCl}_{3}, 400 \mathrm{MHz}\right) \delta 7.46(\mathrm{~s}, 1 \mathrm{H}), 7.60(\mathrm{t}, 1 \mathrm{H}, J=$ $8 \mathrm{~Hz}), 7.76(\mathrm{t}, 1 \mathrm{H}, J=8 \mathrm{~Hz}), 8.04(\mathrm{~d}, 1 \mathrm{H}, J=$ $8 \mathrm{~Hz}), 8.22(\mathrm{~d}, 1 \mathrm{H}, J=8 \mathrm{~Hz}) ;{ }^{13} \mathrm{C} \mathrm{NMR}\left(\mathrm{CDCl}_{3}\right.$, $400 \mathrm{MHz}) \delta 122.97,123.58,125.06,127.13,129.02$, $132.36,144.51,148.55,149.86$. The $\mathrm{C}, \mathrm{H}$ and $\mathrm{N}$ contents were determined by elemental analysis (Anal. Calcd. for $\mathrm{C}_{9} \mathrm{H}_{5} \mathrm{NCl}_{2}$ (\%) C 54.58, H 2.54, N 7.07; found C 54.36, H 2.17, N 6.59).

\section{1c Synthesis of 4-chloroquinolin-2(1H)-one (8):} 2,4-Dichloroquinoline $(521 \mathrm{mg}, 2.63 \mathrm{mmol})$ was dissolved in the mixture of sodium acetate $(425 \mathrm{mg}$, $5.24 \mathrm{mmol})$ in glacial $\mathrm{AcOH}(3 \mathrm{ml}, 52.4 \mathrm{mmol})$. The resulting solution was refluxed by stirring for half an hour. The content was cooled and neutralized with aqueous $\mathrm{NaHCO}_{3}$. The precipitated white solid was filtered and dried under suction. TLC analysis confirmed the formation of the product. The dechlorinated product (375 mg, 79.34\%) was isolated through column chromatography using petroleum ether: ethyl acetate (15\%) as eluent. $\mathrm{mp} 257^{\circ} \mathrm{C}$; IR (KBr) $3311,1656,1030 \mathrm{~cm}^{-1}$; ${ }^{1} \mathrm{H} \mathrm{NMR}\left(\mathrm{CDCl}_{3}, 400 \mathrm{MHz}\right) \delta 5.88(\mathrm{~s}, 1 \mathrm{H}), 7.32(\mathrm{t}$, $1 \mathrm{H}, J=8 \mathrm{~Hz}), 7.45(\mathrm{~d}, 1 \mathrm{H}, J=8 \mathrm{~Hz}), 7.60(\mathrm{t}, 1 \mathrm{H}$, $J=8 \mathrm{~Hz}), 7.96(\mathrm{~d}, 1 \mathrm{H}, J=8 \mathrm{~Hz}), 12.45(\mathrm{bs}, 1 \mathrm{H}$,$) ;$ ${ }^{13} \mathrm{C} \mathrm{NMR}\left(\mathrm{CDCl}_{3}, 400 \mathrm{MHz}\right) \delta 111.87,123.32,125.00$, $127.42,133.21,139.43,148.58,152.09,163.58$. The C, $\mathrm{H}$ and $\mathrm{N}$ contents were determined by elemental analysis (Anal. Calcd. for $\mathrm{C}_{9} \mathrm{H}_{6} \mathrm{NOCl}(\%) \mathrm{C} 60.19$, H 3.37, N 7.80; found C 60.07, H 3.19, N 7.65).

\section{1d Synthesis 4-methoxyquinolin-2(1H)-one (9):} Dimethylformamide (DMF) solution $(5 \mathrm{~mL})$ of 4chloro- $1 H$-quinolin-2-one $(537 \mathrm{mg}, 2.99 \mathrm{mmol})$ was added dropwise to the refluxing mixture of the sodium methoxide $(5.5 \mathrm{~g}, 40 \mathrm{mmol})$ in the $5 \mathrm{ml}$ of DMF. The reaction mixture was further refluxed by stirring for $3 \mathrm{~h}$. Product formation was confirmed by TLC. The mixture was cooled to room temperature and most of the solvent was removed under reduced pressure. The residue was neutralized with $5 \% \mathrm{HCl}$ and the precipitated solid was filtered and dried under suction. The product (370 mg, 70.64\%) was isolated through column chromatography using petroleum ether:ethyl acetate (12\%) as eluent. $\mathrm{mp} 239^{\circ} \mathrm{C}$; IR (KBr) $3311,1654 \mathrm{~cm}^{-1}$; ${ }^{1} \mathrm{H}$ NMR (DMSO, $\left.400 \mathrm{MHz}\right) \delta 4.03$ (s, 3H), 5.81 (s,
1H), 7.31-7.42 (m, 2H), $7.63(\mathrm{t}, 1 \mathrm{H}, J=8 \mathrm{~Hz}), 7.97$ $(\mathrm{d}, 1 \mathrm{H}, J=8 \mathrm{~Hz}$ ), 11.13 (bs, $1 \mathrm{H}) ;{ }^{13} \mathrm{C}$ NMR (DMSO, $400 \mathrm{MHz}) \delta 66.12,110.95,120.61,124.42,128.82$, $132.27,137.14,146.12,164.21,167.34$. The $\mathrm{C}, \mathrm{H}$ and $\mathrm{N}$ contents were determined by elemental analysis (Anal. Calcd. for $\mathrm{C}_{10} \mathrm{H}_{9} \mathrm{NO}_{2}(\%) \mathrm{C} 68.56, \mathrm{H} 5.18, \mathrm{~N}$ 8.00; found C 68.29, H 5.04, N 7.43).

\section{1e Synthesis of 2-chloro-4-methoxyquinoline (10):}

The methoxy compound 9 was chlorinated by following the procedure explained in the synthesis of compound 7. The product $(340 \mathrm{mg}, 61.52 \%)$ was isolated through column chromatography using petroleum ether:ethyl acetate $(6 \%)$ as eluent. $\mathrm{mp} 92^{\circ} \mathrm{C}$; IR $(\mathrm{KBr})$ $1680,896 \mathrm{~cm}^{-1} ;{ }^{1} \mathrm{H}$ NMR $\left(\mathrm{CDCl}_{3}, 400 \mathrm{MHz}\right) \delta 3.8$ (s, 3H), $7.46(\mathrm{~s}, 1 \mathrm{H}), 7.65(\mathrm{t}, 1 \mathrm{H}, J=8 \mathrm{~Hz}), 7.81$ $(\mathrm{d}, 1 \mathrm{H}, J=8 \mathrm{~Hz}), 7.92(\mathrm{t}, 1 \mathrm{H}, J=8 \mathrm{~Hz}), 8.11$ $(\mathrm{d}, 1 \mathrm{H}, J=8 \mathrm{~Hz}) ;{ }^{13} \mathrm{C}$ NMR $\left(\mathrm{CDCl}_{3}, 400 \mathrm{MHz}\right) \delta$ $66.50,113.12,122.57,124.51,128.19,133.59,140.35$, $149.14,153.44,164.37$. The $\mathrm{C}, \mathrm{H}$ and $\mathrm{N}$ contents were determined by elemental analysis (Anal. Calcd. for $\mathrm{C}_{10} \mathrm{H}_{8} \mathrm{NOCl}(\%) \mathrm{C} 62.03, \mathrm{H} 4.16, \mathrm{~N} 7.23$; found $\mathrm{C}$ 61.58, H 4.02, N 7.11).

2.1f Synthesis of of 2-chloro-3-methylquinoline (12): Dimethyl formamide $(7 \mathrm{~mL}, 0.09 \mathrm{~mol})$ was taken in a round bottom flask and stirred under ice-cold condition $\left(5^{\circ} \mathrm{C}\right)$. To this, $\mathrm{POCl}_{3}(23 \mathrm{~mL}, 0.25 \mathrm{~mol})$ was added dropwise for $30 \mathrm{~min}$. The mixture was stirred for an hour in ice-cold condition. After chloromethyliminium species was formed, $\mathrm{N}$-phenylpropionamide (7.45 g, $50 \mathrm{mmol}$ ) was added portion-wise. The whole mixture was further stirred for an hour at room temperature. Then the reaction set-up was transferred to an oil bath and refluxed for $14 \mathrm{~h}$. The temperature was maintained between $70^{\circ}$ and $80^{\circ} \mathrm{C}$. After the reaction was over, the mixture was poured into excess of crushed ice $(1 \mathrm{~kg})$. The white crude product was recrystallized using ethanol and yielded $6.63 \mathrm{~g}, 75 \%$. mp $114^{\circ} \mathrm{C}$; IR (KBr) $1622,1031 \mathrm{~cm}^{-1} ;{ }^{1} \mathrm{H}$ NMR $\left(\mathrm{CDCl}_{3}, 400 \mathrm{MHz}\right) \delta 2.48$ $(\mathrm{s}, 3 \mathrm{H}), 7.52(\mathrm{t}, 1 \mathrm{H}, J=7.6 \mathrm{~Hz}), 7.65(\mathrm{t}, 1 \mathrm{H}, J=$ $7.8 \mathrm{~Hz}), 7.72(\mathrm{~d}, 1 \mathrm{H}, J=7.8 \mathrm{~Hz}), 7.94(\mathrm{~s}, 1 \mathrm{H}), 7.99$ $(\mathrm{d}, 1 \mathrm{H}, J=8.1 \mathrm{~Hz}) ;{ }^{13} \mathrm{C} \mathrm{NMR}\left(\mathrm{CDCl}_{3}, 400 \mathrm{MHz}\right) \delta$ 20.19, 126.67, 126.95, 127.81, 128.42, 129.16, 130.32, $138.02,146.09,151.68$. The $\mathrm{C}, \mathrm{H}$ and $\mathrm{N}$ contents were determined by elemental analysis (Anal. Calcd. for $\mathrm{C}_{10} \mathrm{H}_{8} \mathrm{NCl}(\%) \mathrm{C} 67.62, \mathrm{H} 4.54, \mathrm{~N} 7.89$; found C 67.57, $\mathrm{H} 4.33$, N 7.69).

\section{1g Synthesis of 3-(bromomethyl)-2-chloroquinoline} (13): 2-Chloro-3-methylquinoline $(530 \mathrm{mg}, 3 \mathrm{mmol})$ was dissolved in $\mathrm{CCl}_{4}(40 \mathrm{ml})$. To this, catalytic amount of benzoylperoxide ( $50 \mathrm{mg}, 0.02 \mathrm{mmol}$ ) was added. The 
mixture was stirred under ice-cold condition for $10 \mathrm{~min}$. Then $N$-bromosuccinimide $(748 \mathrm{mg}, 4.2 \mathrm{mmol}$ ) was added. The whole mixture was stirred further under icecold condition for an hour. Product formation was confirmed by TLC and succinimide was removed (which was insoluble in $\mathrm{CCl}_{4}$ ) by filtration and washed with $20 \mathrm{ml}$ of $\mathrm{CCl}_{4}$. The contents of the filtrate were reduced to half, and the residue was subjected to silica gel column chromatography using petroleum ether and ethyl acetate as eluent $(2 \%)$, which yields colourless needle product $510 \mathrm{mg}, 67 \%$. $\mathrm{mp} 116^{\circ} \mathrm{C}$; IR (KBr) 2916, $1600,1014,732 \mathrm{~cm}^{-1} ;{ }^{1} \mathrm{H} \mathrm{NMR}\left(\mathrm{CDCl}_{3}, 400 \mathrm{MHz}\right) \delta$ $4.7(\mathrm{~s}, 2 \mathrm{H}), 7.59$ (t, $1 \mathrm{H}, J=8 \mathrm{~Hz}), 7.73-7.83(\mathrm{~m}, 2 \mathrm{H})$, 8.0-8.1 (m, 1H), 8.2-8.3 (m, 1H); ${ }^{13} \mathrm{C}$ NMR $\left(\mathrm{CDCl}_{3}\right.$, $400 \mathrm{MHz}) \delta 38.42,126.56,127.50,127.78,128.09$, $129.66,133.60,136.99,140.36,148.73$. The $\mathrm{C}, \mathrm{H}$ and $\mathrm{N}$ contents were determined by elemental analysis (Anal. Calcd. for $\mathrm{C}_{10} \mathrm{H}_{7} \mathrm{NBrCl}(\%) \mathrm{C} 46.82, \mathrm{H}$ 2.75, N 5.4; found $\mathrm{C} 46.43, \mathrm{H} 2.58, \mathrm{~N} 5.18$ ).

2.1h Synthesis of 4-(2-chloro-phenylamino)-1H-quinolin-2-one (14): $\mathrm{KOH}(1.5 \mathrm{~g}, 26.74 \mathrm{mmol})$ in $t$-butyl alcohol ( $2 \mathrm{~mL}, 21.07 \mathrm{mmol})$ was stirred at room temperature for $30 \mathrm{~min}$. To this potassium salt, $o$-chloroaniline $(0.3 \mathrm{~mL}, 2.68 \mathrm{mmol})$ was added and refluxed for $10 \mathrm{~min}$. To this refluxing solution, the 4-chloroquinolin-2(1H)one (8) (482 mg, $2.68 \mathrm{mmol}$ ) was added. The whole mixture was refluxed by constant stirring for $12 \mathrm{~h}$. Product formation was confirmed by TLC. The crude mixture was poured into crushed ice. The resulting precipitate was extracted with ethylacetate and the organic layer was adsorbed for column chromatography using petroleum ether and ethyl acetate mixture as eluent, which resulted in the pure yellow product (375 mg, 51.62\%). mp $276^{\circ} \mathrm{C}$; IR (KBr) 3168, 3010, 1656, $742 \mathrm{~cm}^{-1} ;{ }^{1} \mathrm{H} \mathrm{NMR}\left(\mathrm{CDCl}_{3}, 400 \mathrm{MHz}\right) \delta 6.41$ (s, 1H), 6.56-6.64 (m, 1H), 7.32-7.41 (m, 2H), 7.55$7.60(\mathrm{~m}, 1 \mathrm{H}), 7.65(\mathrm{~d}, 1 \mathrm{H}, J=8 \mathrm{~Hz}), 7.83(\mathrm{~d}, 1 \mathrm{H}$, $J=8 \mathrm{~Hz}), 7.94(\mathrm{~d}, 1 \mathrm{H}, J=8 \mathrm{~Hz}), 8.10-8.13(\mathrm{~m}$, $1 \mathrm{H}), 9.87$ (s, $1 \mathrm{H}), 12.5$ (bs, $1 \mathrm{H}) ;{ }^{13} \mathrm{C} \mathrm{NMR}\left(\mathrm{CDCl}_{3}\right.$, $400 \mathrm{MHz}) \delta 112.70,119.19,119.65,121.83,122.21$, $122.40,123.69,127.16,132.80,134.36,137.12$, $139.67,142.75,147.64,161.17$. The $\mathrm{C}, \mathrm{H}$ and $\mathrm{N}$ contents were determined by elemental analysis (Anal. Calcd. for $\mathrm{C}_{15} \mathrm{H}_{11} \mathrm{~N}_{2} \mathrm{OCl}(\%) \mathrm{C} 66.55, \mathrm{H}$ 4.10, $\mathrm{N}$ 10.35; found $\mathrm{C} 66.32, \mathrm{H} 3.92, \mathrm{~N} 10.12$ ).

\section{1i Synthesis of 5H-indolo[3,2-c]quinolin-6(11H)-one}

(1): The anilated compound (14) (498 mg, $1.84 \mathrm{mmol})$ and palladium(II)acetate $(500 \mathrm{mg}, 2.23 \mathrm{mmol})$ were refluxed in toluene $(50 \mathrm{ml})$ with $150 \mathrm{mg}$ of potassium carbonate $(1.09 \mathrm{mmol})$ for $10 \mathrm{~h}$. Formation of the pro- duct was confirmed by TLC. The solvent was removed under reduced pressure and the residue was dissolved in ethyl acetate. The solution was washed with brine solution and the combined organic layers were dried over anhydrous sodium sulphate. The product was isolated by silica gel column chromatography, which resulted in a pale yellow precipitate $(220 \mathrm{mg}, 51.05 \%) \mathrm{mp}$ $312^{\circ} \mathrm{C}$; IR (KBr) 3438, 3333, 3192, $1641 \mathrm{~cm}^{-1} ;{ }^{1} \mathrm{H}$ NMR (DMSO, $400 \mathrm{MHz}) \delta 7.2$ to $8.1(\mathrm{~m}, 8 \mathrm{H}), 11.27$ (s, 1H), $12.2(\mathrm{bs}, 1 \mathrm{H}) ;{ }^{13} \mathrm{C}$ NMR (DMSO, $400 \mathrm{MHz}$ ) $\delta 115.42,119.13,119.22,122.29,122.45,123.74$, $127.20,132.96,137.20,139.97,142.47,147.12$, $152.50,154.92,161.07$. The $\mathrm{C}, \mathrm{H}$ and $\mathrm{N}$ contents were determined by elemental analysis (Anal. Calcd. for $\mathrm{C}_{15} \mathrm{H}_{10} \mathrm{~N}_{2} \mathrm{O}$ (\%) $\mathrm{C}$ 76.91, H 4.30, N 11.94; found $\mathrm{C}$ 76.34, H 4.07, N 11.54).

\section{$2.1 \mathrm{j}$ Synthesis of 6-chloro-11H-indolo[3,2-c]quinoline}

(15): Chlorination of $5 H, 11 H$,-indolo[3,2-c] quinolin6-one $1(250 \mathrm{mg}, 1.06 \mathrm{mmol})$ was done by following the procedure explained in the preparation of compound 7. White precipitate $(176 \mathrm{mg}, 65.26 \%) \mathrm{mp} 182^{\circ} \mathrm{C}$; IR (KBr) 3050, 1587, 1030, $747 \mathrm{~cm}^{-1} ;{ }^{1} \mathrm{H} \mathrm{NMR}\left(\mathrm{CDCl}_{3}\right.$, $400 \mathrm{MHz}) \delta 7.25-7.36(\mathrm{~m}, 2 \mathrm{H}), 7.58-7.85(\mathrm{~m}, 2 \mathrm{H})$, 7.98-8.20 (m, 4H), $11.2(\mathrm{~s}, 1 \mathrm{H}) ;{ }^{13} \mathrm{C} \mathrm{NMR}\left(\mathrm{CDCl}_{3}\right.$, $400 \mathrm{MHz}) \delta 113.28,114.89,122.70,124.57,124.84$, $126.04,130.91,134.64,139.51,144.86,147.66$, $150.00,154.22,156.69,157.79$. The $\mathrm{C}, \mathrm{H}$ and $\mathrm{N}$ contents were determined by elemental analysis (Anal. Calcd. for $\mathrm{C}_{15} \mathrm{H}_{9} \mathrm{~N}_{2} \mathrm{Cl}$ (\%) C 71.30, H 3.59, N 11.09; found $\mathrm{C} 71.12, \mathrm{H} \mathrm{3.45,} \mathrm{N} \mathrm{10.75).}$

$2.1 \mathrm{k}$ Synthesis of 6-methoxy-11H-indolo[3,2-c]quinoline (2): Methoxylation of 6-chloro- $11 H$-indolo[3,2-c]quinoline 15 (25 mg, $1 \mathrm{mmol}$ ) was done by following the procedure explained in the preparation of compound 9, which resulted in a dirty white precipitate $(14 \mathrm{mg}$, $56.99 \%$ ). mp $257^{\circ} \mathrm{C}$; IR (KBr) 3052, $1744 \mathrm{~cm}^{-1} ;{ }^{1} \mathrm{H}$ NMR $\left(\mathrm{CDCl}_{3}, 400 \mathrm{MHz}\right) \delta 3.84(\mathrm{~s}, 3 \mathrm{H}), 7.24-8.10(\mathrm{~m}$, $8 \mathrm{H}), 11.16(\mathrm{~s}, 1 \mathrm{H}),{ }^{13} \mathrm{C} \mathrm{NMR}\left(\mathrm{CDCl}_{3}, 400 \mathrm{MHz}\right) \delta$ $62.72,113.42,116.09,126.09,126.56,127.50,127.78$, $128.09,129.66,133.60,136.99,140.36,148.73$, $148.94,155.33,165.04$. The $\mathrm{C}, \mathrm{H}$ and $\mathrm{N}$ contents were determined by elemental analysis (Anal. Calcd. for $\mathrm{C}_{16} \mathrm{H}_{12} \mathrm{~N}_{2} \mathrm{O}$ (\%) C 77.40, $\mathrm{H}$ 4.87, N 11.28; found $\mathrm{C}$ 77.16, H 4.25, N 11.02).

\subsection{Synthesis of $N$-(2-chlorophenyl)-4-methoxyquinolin-}

2-amine (16): Reaction of 2-chloro-4-methoxyquinoline $(519 \mathrm{mg}, 2.68 \mathrm{mmol})$ with $o$-chloroaniline $0.3 \mathrm{~mL}(2.68 \mathrm{mmol})$ was done by following the procedure explained in the preparation of compound 14, which resulted in a yellow precipitate of $\mathbf{1 6}(450 \mathrm{mg}$, 
58.97\%). mp $142^{\circ} \mathrm{C}$; IR (KBr) 3350, 1687, $1053 \mathrm{~cm}^{-1}$; ${ }^{1} \mathrm{H}$ NMR (DMSO, $\left.400 \mathrm{MHz}\right) \delta 3.92$ (s, 3H), 6.40-6.49 (m, 1H), 6.87-6.94 (m, 1H), 7.24-7.37 (m, 3H), 7.61 $(\mathrm{t}, 2 \mathrm{H}, J=8 \mathrm{~Hz}), 7.91(\mathrm{~d}, 1 \mathrm{H}, J=8 \mathrm{~Hz}), 8.16-8.28$ $(\mathrm{m}, 1 \mathrm{H}), 9.8(\mathrm{~s}, 1 \mathrm{H}) ;{ }^{13} \mathrm{C}$ NMR (DMSO, $\left.400 \mathrm{MHz}\right)$ $\delta 114.90,115.97,116.30,118.48,119.32,120.29$, $123.23,125.15,131.88,134.34,137.83,144.68$, $146.55,156.19,162.47$. The $\mathrm{C}, \mathrm{H}$ and $\mathrm{N}$ contents were determined by elemental analysis (Anal. Calcd. for $\mathrm{C}_{16} \mathrm{H}_{13} \mathrm{~N}_{2} \mathrm{OCl}$ (\%) $\mathrm{C} 67.49, \mathrm{H} 4.60, \mathrm{~N}$ 9.84; found $\mathrm{C}$ 66.35, H 4.42, N 9.65).

$2.1 \mathrm{~m}$ Synthesis of 11-methoxy-6H-indolo[2,3-b] quinoline (3): Palladium complex catalysing intramolecular cyclization of (2-chloro-phenyl)-(4-methoxyquinolin-2-yl)-amine (523 mg, $1.84 \mathrm{mmol}$ ) was done by following the procedure explained in the preparation of compound $\mathbf{1}$, which resulted in a dirty white precipitate of 3 ( $270 \mathrm{mg}, 59.21 \%)$. mp $234^{\circ} \mathrm{C}$; IR (KBr) $3380,1614 \mathrm{~cm}^{-1} ;{ }^{1} \mathrm{H}$ NMR (DMSO, $\left.400 \mathrm{MHz}\right) \delta 4.04$ (s, 3H), 7.11-7.20 (m, 2H), 7.31-7.36 (m, 1H), 7.37$7.44(\mathrm{~m}, 2 \mathrm{H}), 7.48-7.53(\mathrm{~m}, 1 \mathrm{H}), 7.72(\mathrm{~d}, 1 \mathrm{H}, J=$ $8 \mathrm{~Hz}), 7.78-7.83(\mathrm{~m}, 1 \mathrm{H}), 11.12(\mathrm{~s}, 1 \mathrm{H},) ;{ }^{13} \mathrm{C}$ NMR (DMSO, $400 \mathrm{MHz}) \delta 68.04,111.97,118.61,121.90$, $122.60,124.54,126.37,130.89,134.94,135.12$, $139.63,143.58,144.04,147.27,157.10,164.59$. The C, $\mathrm{H}$ and $\mathrm{N}$ contents were determined by elemental analysis (Anal. Calcd. for $\mathrm{C}_{16} \mathrm{H}_{12} \mathrm{~N}_{2} \mathrm{O}$ (\%) C 77.40, H 4.87, $\mathrm{N}$ 11.28; found C 77.25, H 4.51, N 11.14).

2.1n Synthesis of 1-(2-chloro-quinolin-3-ylmethyl)1H-pyridin-2-one (17): Reaction of 3-bromomethyl2-chloro-quinoline $(0.5 \mathrm{~g}, 1.95 \mathrm{mmol})$ with $1 \mathrm{H}$-pyridin2-one $185 \mathrm{mg}(1.95 \mathrm{mmol})$ was done by following the procedure explained in the preparation of compound 14, which resulted in a greenish yellow precipitate of $17(320 \mathrm{mg}, 60.64 \%)$. mp $123^{\circ} \mathrm{C}$; IR (KBr) 1686 , $1589,1031 \mathrm{~cm}^{-1} ;{ }^{1} \mathrm{H}$ NMR (DMSO, $\left.400 \mathrm{MHz}\right) \delta 4.02$ (s, 2H), 6.38-6.46 (m, 2H), 7.38-8.06 (m, 5H), 8.23 (s, $1 \mathrm{H}), 8.67(\mathrm{~d}, 1 \mathrm{H}, J=8 \mathrm{~Hz}) ;{ }^{13} \mathrm{C}$ NMR (DMSO, $400 \mathrm{MHz}) \delta 51.18,110.03,120.80,122.93,123.29$, $126.85,130.07,132.47,135.12,140.55,143.78$, $148.27,152.14,157.86,166.48$. The $\mathrm{C}, \mathrm{H}$ and $\mathrm{N}$ contents were determined by elemental analysis (Anal. Calcd. for $\mathrm{C}_{15} \mathrm{H}_{11} \mathrm{~N}_{2} \mathrm{OCl}(\%) \mathrm{C} 66.55, \mathrm{H}$ 4.10, N 10.35; found $\mathrm{C} 66.24, \mathrm{H} 3.98, \mathrm{~N} 10.21$ ).

2.1o Synthesis of indolizino[1,2-b]quinolin-9(11H)one (4): Palladium complex catalysing intramolecular cyclization of 1-(2-chloro-quinolin-3-ylmethyl)$1 \mathrm{H}$-pyridin-2-one $(0.498 \mathrm{~g}, 1.84 \mathrm{mmol})$ was done by following the procedure explained in the preparation of compound 1, which resulted in a pale yellow precipitate (270 mg 62.66\%). mp $242^{\circ} \mathrm{C}$; IR (KBr) 1688 , $1579 \mathrm{~cm}^{-1} ;{ }^{1} \mathrm{H}$ NMR (DMSO, $\left.400 \mathrm{MHz}\right) \delta 4.25(\mathrm{~s}, 2 \mathrm{H})$, 6.78-6.85 (m, 2H), $7.25(\mathrm{t}, 1 \mathrm{H}, J=8 \mathrm{~Hz}), 7.43(\mathrm{t}$, $1 \mathrm{H}, J=8 \mathrm{~Hz}), 7.65(\mathrm{~d}, 1 \mathrm{H}, J=8 \mathrm{~Hz}), 7.74-7.78(\mathrm{~m}$, $1 \mathrm{H}), 7.91(\mathrm{~d}, 1 \mathrm{H}, J=8 \mathrm{~Hz}), 8.27(\mathrm{~s}, 1 \mathrm{H}) ;{ }^{13} \mathrm{C} \mathrm{NMR}$ (DMSO, $400 \mathrm{MHz}) \delta 54.22,109.96,116.47,119.92$, $121.38,124.12,126.27,131.54,138.92,141.73$, 145.92, 149.86, 155.17, 158.51, 163.62. The C, $\mathrm{H}$ and $\mathrm{N}$ contents were determined by elemental analysis (Anal. Calcd. for $\mathrm{C}_{15} \mathrm{H}_{10} \mathrm{~N}_{2} \mathrm{O}$ (\%) C 76.91, H 4.30, N 11.94; found $\mathrm{C} 76.12, \mathrm{H} 4.09, \mathrm{~N}$ 11.27).

2.1p Synthesis of $N$-((2-chloroquinolin-3-yl)methyl) pyridin-2-amine (18): The 1:1 equimolar mixture of 3-bromomethyl-2-chloro-quinoline $500 \mathrm{mg}(1.95 \mathrm{mmol})$ and pyridin-2-ylamine $184 \mathrm{mg}(1.95 \mathrm{mmol})$ in $10 \mathrm{ml}$ of acetonitrile were stirred at room temperature. To this mixture, $1 \mathrm{ml}$ of triethylamine was added dropwise. The whole mixture was stirred further for an hour. After the reaction was over, the content of the reaction mixture was reduced and the residue was subjected to silica gel column chromatography which yields a pure yellow precipitate $(330 \mathrm{mg}, 62.77 \%)$ in the petroleum ether and ethyl acetate medium (4\%). mp $237^{\circ} \mathrm{C}$; IR (KBr) 3410, 3052, 1617, 1033, $742 ;{ }^{1} \mathrm{H}$ NMR $\left(\mathrm{CDCl}_{3}\right.$, $400 \mathrm{MHz}) \delta 4.26(\mathrm{~s}, 2 \mathrm{H}), 6.64-6.73(\mathrm{~m}, 1 \mathrm{H}), 7.02$ $(\mathrm{d}, 1 \mathrm{H}, J=8 \mathrm{~Hz}), 7.41-7.69(\mathrm{~m}, 4 \mathrm{H}), 7.75-7.90$ $(\mathrm{m}, 2 \mathrm{H}), 8.06(\mathrm{~d}, 1 \mathrm{H}, J=8 \mathrm{~Hz}), 10.12(\mathrm{~s}, 1 \mathrm{H})$; ${ }^{13} \mathrm{C} \mathrm{NMR}\left(\mathrm{CDCl}_{3}, 400 \mathrm{MHz}\right) \delta 47.16,108.46,110.55$, $122.93,124.11,125.44,128.16,128.97,134.10$, $138.07,142.56,144.02,145.98,152.73,157.38$. The C, $\mathrm{H}$ and $\mathrm{N}$ contents were determined by elemental analysis (Anal. Calcd. for $\mathrm{C}_{15} \mathrm{H}_{12} \mathrm{~N}_{3} \mathrm{Cl}$ (\%) C 66.79, $\mathrm{H} 4.48$, N 15.58; found C 66.16, H 4.14, N 14.97).

2.1q Synthesis of 5,6-dihydrobenzo[b]pyrido[2,3-h] [1,6]naphthyridine (5): Palladium complex catalysing intramolecular cyclization of 2-chloro-quinolin3-ylmethyl)-pyridin-2-yl-amine (496 mg, $1.84 \mathrm{mmol}$ ) was done by following the procedure explained in the preparation of compound $\mathbf{1}$, which resulted in a greenish white precipitate $(275 \mathrm{mg}, 64.11 \%) . \mathrm{mp} 312^{\circ} \mathrm{C}$. IR (KBr) $3311,1654,1516 \mathrm{~cm}^{-1} ;{ }^{1} \mathrm{H}$ NMR $\left(\mathrm{CDCl}_{3}\right.$, $400 \mathrm{MHz}) \delta 4.21(\mathrm{~s}, 2 \mathrm{H}), 6.94(\mathrm{t}, 1 \mathrm{H}, J=8 \mathrm{~Hz})$ $7.21(\mathrm{t}, 1 \mathrm{H}, J=8 \mathrm{~Hz}), 7.47-7.60(\mathrm{~m}, 2 \mathrm{H}), 7.76$ $(\mathrm{d}, 1 \mathrm{H}, J=8 \mathrm{~Hz}), 7.98-8.09(\mathrm{~m}, 2 \mathrm{H}), 8.44(\mathrm{~d}, 1 \mathrm{H}$, $J=8 \mathrm{~Hz}), 10.18(\mathrm{~s}, 1 \mathrm{H}) ;{ }^{13} \mathrm{C} \mathrm{NMR}\left(\mathrm{CDCl}_{3}, 400 \mathrm{MHz}\right)$ $\delta 52.13,115.13,121.04,121.98,122.03,126.15$, $126.47,127.48,129.09,135.45,138.22,145.75$, $148.62,155.90,156.75$. The $\mathrm{C}, \mathrm{H}$ and $\mathrm{N}$ contents were 
determined by elemental analysis (Anal. Calcd. for $\mathrm{C}_{15} \mathrm{H}_{10} \mathrm{~N}_{2} \mathrm{O}(\%) \mathrm{C} 77.23, \mathrm{H} 4.75, \mathrm{~N} 18.01$; found $\mathrm{C}$ 76.95, H 4.18, N 17.54).

\subsection{Biology}

2.2a Photoinduced antimicrobial activity: In the photoinduced antimicrobial study, compounds $\mathbf{1}$ to $\mathbf{5}$ were screened for antimicrobial and photosensitizing activities by the disc diffusion method. ${ }^{25}$ The test organism used was B. subtilis. Pre-experimental procedure of the activity analysis is as follows:

a. Nutrient agar medium: $0.3 \%$ of beef extract, $0.5 \%$ of peptone, $0.1 \%$ of dipotassium hydrogen phosphate, and $1.5 \%$ of agar.

b. Broth culture of the organism B. subtilis was incubated overnight and then broth culture of the organism was prepared.

c. Paper discs: Whatman No. 1 filter paper disc $(6 \mathrm{~mm})$ was sterilized and impregnated with the tested compounds in DMF solution and allowed to dry overnight.

The prepared broth culture $(0.02 \mathrm{~mL})$ was added carefully to sterile Petri dishes and then $10 \mathrm{~mL}$ of liquefied nutrient agar medium was added. It was allowed to be mixed uniformly and the agar layer solidified. Each plate contains a disc impregnated with DMF (neglect effect of the solvent). Two groups of plates were used, one as test plate was incubated in the dark at $37^{\circ} \mathrm{C}$ for $3 \mathrm{~h}$ before irradiation to allow for diffusion of the tested compounds through the agar layer, and the duplicate plate was left in the incubator overnight as control to determine antimicrobial activity. Covers were removed from the tested Petri dishes and exposed to UV lamp $(365 \mathrm{~nm})$ for $20 \mathrm{~min}$. After irradiation, the plates were reincubated in the dark at $37^{\circ} \mathrm{C}$ overnight and examined for antimicrobial and photosensitizing activities by measuring the produced inhibition zones.

\section{2b DNA binding experiments: All the experiments} involving interaction of the compound 1 with DNA were carried out in Tris- $\mathrm{HCl}$ buffer $(50 \mathrm{mM}$ Tris- $\mathrm{HCl}$, $\mathrm{pH}$ 7.2) at room temperature. ${ }^{26}$ Purification of the CT DNA was performed by the reported procedure. The absorption titration experiments were performed by varying concentration of CT DNA while keeping the compound concentration as constant $[0.75 \mathrm{~mL}, 10 \mu \mathrm{M}]$. The spectra were recorded after equilibration for $5 \mathrm{~min}$. The UV-titration of the solution was directly taken in a 1-cm path length quartz cuvette at room temperature using a Shimadzu UV-NIR Spectrometer. The change of absorption intensity of the spectral band was monitored on increasing the concentration of CT DNA.

2.2c DNA photoclevage study: The photo-induced DNA cleavage by compound 1 was examined by gel electrophoresis experiment. ${ }^{27}$ Supercoiled pBR322 DNA $(0.1 \mu \mathrm{g})$ was treated with the compound in the buffer ( $50 \mathrm{mM}$ Tris- $\mathrm{HCl}, 18 \mathrm{mM} \mathrm{NaCl}, \mathrm{pH}=7.2$ ), and the solution was then 125 irradiated at room temperature with a UV lamp $(365 \mathrm{~nm}, 10 \mathrm{~W}, 45 \mathrm{~min})$ or Xe lamp ( $450 \mathrm{~nm}, 150 \mathrm{~W}, 60 \mathrm{~min})$. The samples were analysed by electrophoresis for $1.5 \mathrm{~h}$ at $80 \mathrm{~V}$ on a $1 \%$ agarose gel in TBE buffer $(89 \mathrm{mM}$ Tris-borate acid, $2 \mathrm{mM} \mathrm{Na} \mathrm{H}_{2}$ EDTA, $\mathrm{pH}=8.3$ ). The gel was stained with $1 \mu \mathrm{g} / \mathrm{mL}$ ethidium bromide and photographed on an Alpha Innotech IS-5500 fluorescence chemiluminescence and 130 visible imaging system.

In order to identify the actual reactive oxygen species responsible for DNA damage, a number of control experiments were carried out using various types of quenchers. Histidine $(15 \mathrm{mM})$ and $\mathrm{NaN}_{3}(15 \mathrm{mM})$ were used as ${ }^{1} \mathrm{O}_{2}$ quenchers, superoxide dismutase (SOD 100 unit) was used as a superoxide anion radical quencher, mannitol $(15 \mathrm{mM})$ and ethanol $(15 \mathrm{mM})$ were used as $\mathrm{OH}^{\bullet}$ scavengers.

\subsection{Theoretical study}

Theoretical models were simulated using Chembio3D Ultra-11, 2007 software. First the structure models were generated then fully minimized to obtain optimum structures with least energy. The electronic charge distribution curves are plotted after the MM2-dynamic energy.

\section{Results and discussion}

\subsection{Synthesis of heterocyclic ring fused quinoline derivatives}

Synthesis of key intermediates $\mathbf{8}$ and $\mathbf{1 0}$ (scheme 2) is achieved via multi-step synthetic routes starting from 4-hydroxyquinolin-2(1H)one 6. Iinitially, compound 6 is converted to dichloro compound 7 using $\mathrm{POCl}_{3}$ as chlorinating agent. Selective dechlorination at the second position of quinoline ring in compound $\mathbf{7}$ is done by using glacial acetic acid with sodium acetate mixture (1:1 mols ratio). The reaction is performed at $120^{\circ} \mathrm{C}$ for $30 \mathrm{~min}$. Analytical and spectroscopic data confirm the product as 4-chloroquinolin-2one (8). Then the compound $\mathbf{8}$ is methoxylated under the condition of $\mathrm{NaOCH}_{3}$ in DMF medium. The presence of a singlet at $\delta 4\left(\mathrm{Q}-\mathrm{OCH}_{3}\right)$ and a broad singlet at $\delta 12(\mathrm{Q}-\mathrm{N}-\mathrm{H})$ in 


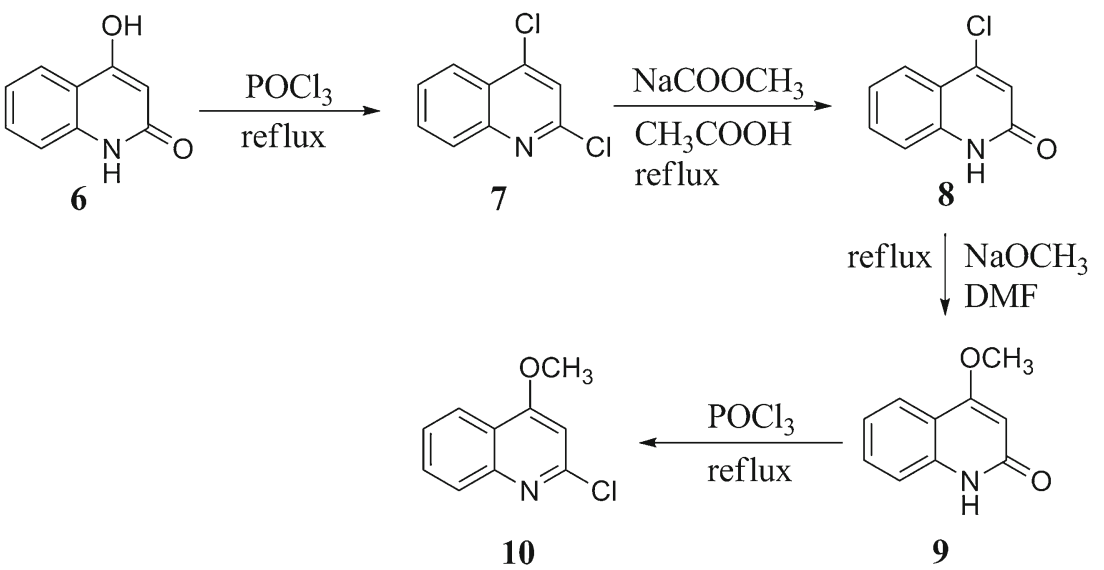

Scheme 2. Synthesis of quinoline precursors $\mathbf{8}$ and $\mathbf{1 0}$ from 4-hydroxyquinolin$2(1 H)$ one through selective chlorination and methoxylation.

the ${ }^{1} \mathrm{H}$ NMR spectrum shows the formation of methoxylated compound $\mathbf{9}$. Finally, the methoxy compound $\mathbf{9}$ is chlorinated using $\mathrm{POCl}_{3}$ to get the active intermediate $\mathbf{1 0}$.

Another starting precursor $\mathbf{1 2}$ is prepared using Vilsmeier-Haack reagent (scheme 3) based on the method of Cohn et al. ${ }^{28}$ It is a straightforward reaction and does not lead to any byproduct. A specific reactant ratio is illustrated [compound 11: DMF: $\mathrm{POCl}_{3}$ in 1: 1.9: 5.5] to give maximum yield of the product (12) with high purification. However, in the preparation of 2-chloro-3-formylquinoline, ${ }^{28}$ formamidine is obtained as an undesired product. Spectral and analytical data confirm the formation of compound $\mathbf{1 2}$. The mechanism for the formation of $\mathbf{1 2}$ is given in the scheme 4.

Methylquinoline compound (12) is subjected to bromination using $N$-bromosuccinimide (NBS) (scheme 3). The reaction is carried out using 1:1.5 mols ratio of compound $\mathbf{1 2}$ and NBS, respectively in $\mathrm{CCl}_{4}$ solvent medium containing catalytic amount of benzoyl peroxide. A singlet at $\delta 3.9$ in the ${ }^{1} \mathrm{H}$ NMR spectrum and 1:1 intensity of the $\mathrm{M}^{+},(\mathrm{M}+2)^{+}$peaks in the mass spectrum of $\mathbf{1 3}$ reveal that bromination has taken place at C3-methyl group of $\mathbf{1 2}$.

During the synthesis of indoloquinoline derivatives $\mathbf{1}$ to $\mathbf{3}$, intermediates $\mathbf{8}$ and $\mathbf{1 0}$ are aminated with 2-chloroaniline and compound $\mathbf{1 3}$ is aminated using pyridin-2(1H)-one under potassium salt of $t$-butyl alcohol basic medium (schemes 5,6 and 7). Aminated quinoline derivatives $\mathbf{1 4}, \mathbf{1 6}$ and $\mathbf{1 7}$ are subjected to intramolecular cyclization using palladium(II)diacetate complex as catalyst to achieve the targeted indoloquinoline derivatives $\mathbf{1}, \mathbf{3}$ and 4 . Mechanism of the intramolecular cyclization process is presented in scheme $8 .^{29-31}$ Further, $\mathbf{1}$ is chlorinated and subsequently methoxylated in order to get another methoxy substitutional indoloquinoline isomer 2 (scheme 5).

Finally, synthesis of quinoline core fused 1,8naphtheridine system (5) is also attempted (scheme 7) based on the photo-bioactivities of 1,8-naphtheridine derivatives. $^{32}$ Initial amination of $\mathbf{1 3}$ with 2aminopyridine was done under room temperature in the acetonitrile medium with few drops of triethylamine base. From the amino compound $\mathbf{1 8}$, compound $\mathbf{5}$ is synthesized by using palladium complex catalysed intramolecular cyclization.

\subsection{Photo-biological activity}

3.2a Antibacterial activity: All the synthesized indoloquinoline derivatives ( $\mathbf{1}$ to $\mathbf{4})$ and 1,8 naphtheridine (5) are tested for their in vitro photoinduced antibacterial activity against $B$. subtilis. Xanthotoxin is used as a standard drug (photo-bioactivity) whose diameter of zone inhibition is furnished in table 1. Generally, all the compounds show a certain

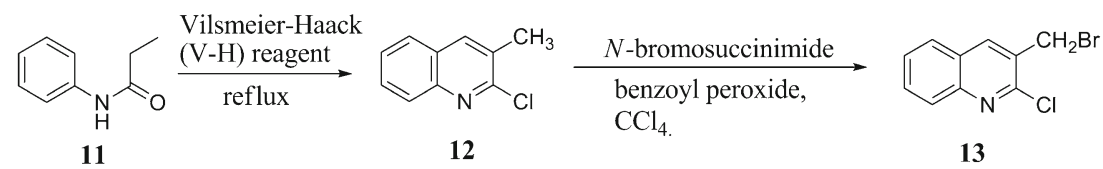

Scheme 3. New attempted synthesis for the 2-chloro-3-methylquinoline using Vilsmeier-Haack reagent and 3-(bromomethyl)-2-chloroquinoline precursors. 


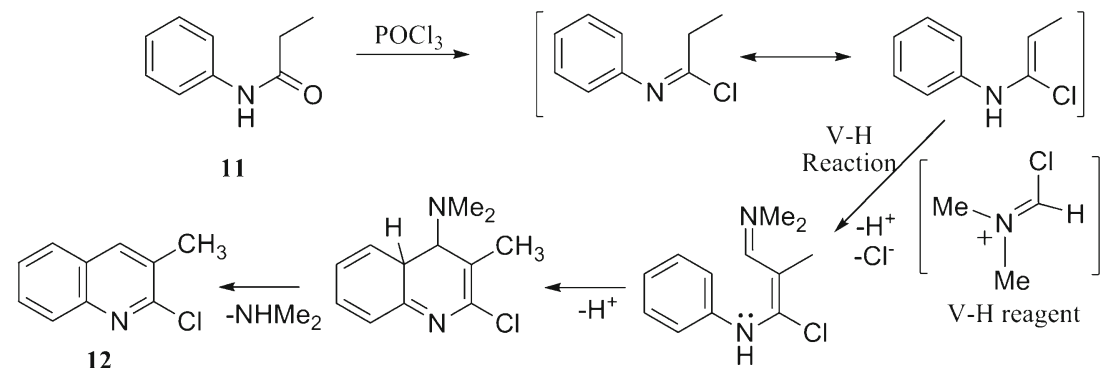

Scheme 4. Possible mechanism for the formation of 2-chloro-3-methylquinoline using Vilsmeier-Haack reagent.

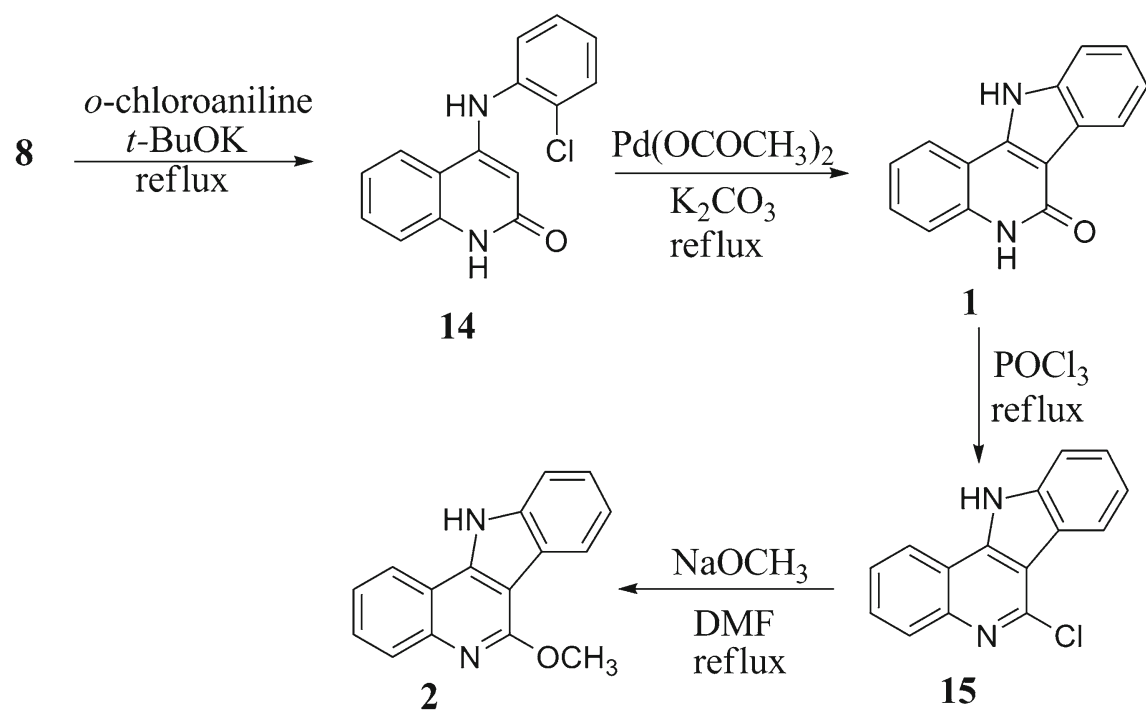

Scheme 5. Condensation of $\mathbf{8}$ with $o$-chloroaniline and palladium complex assisting cyclization. Subsequent chlorination and methoxylation of $\mathbf{1}$ for the synthesis of indoloquinoline 2.
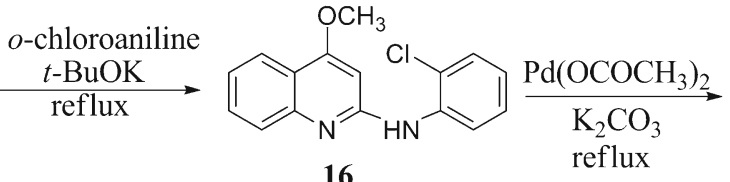<smiles>COc1c2ccccc2nc2[nH]c3ccccc3c12</smiles>

Scheme 6. Condensation of $\mathbf{1 0}$ with $\boldsymbol{o}$-chloroaniline and palladium complex assisting cyclization for the preparation of linear indoloquinoline $\mathbf{3}$.

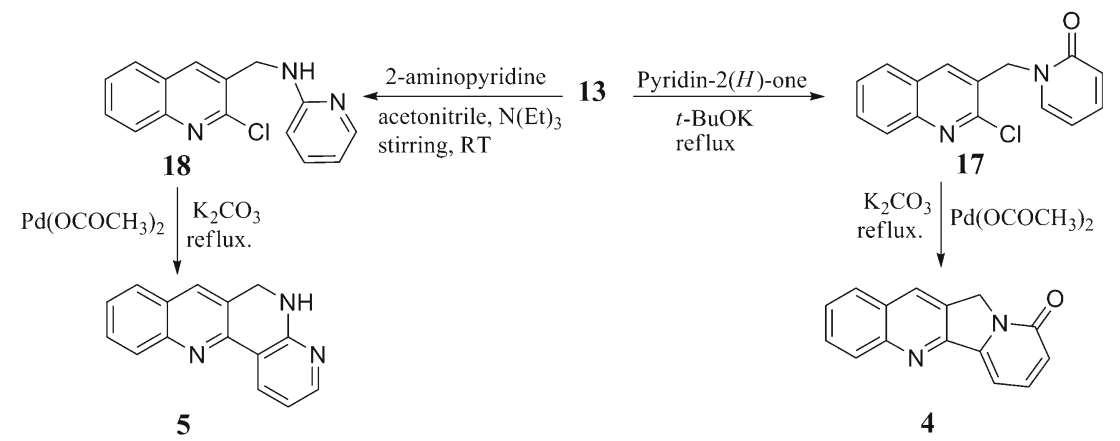

Scheme 7. Condensation of $\mathbf{1 3}$ with pyridine-2(H)-one or 2-aminopyridine and followed by palladium complex assisting cyclization for the synthesis of compounds $\mathbf{4}$ and $\mathbf{5}$. 


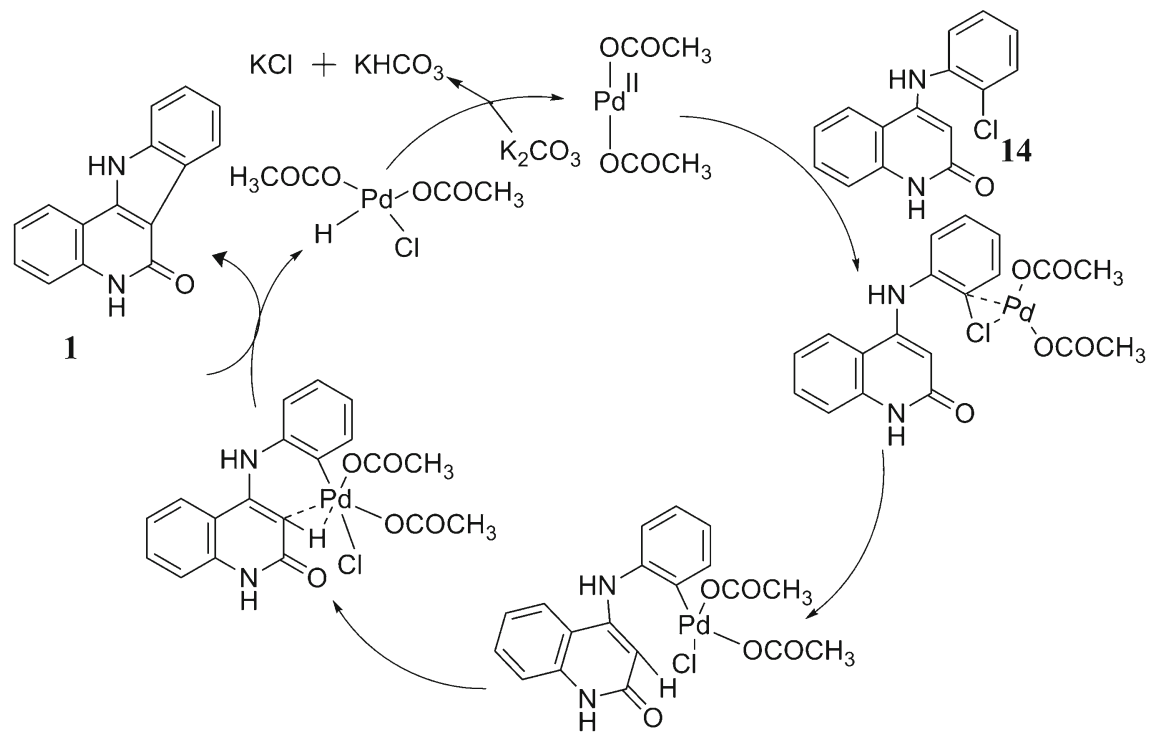

Scheme 8. Proposed mechanism for the palladium complex catalysing intramolecular cyclization of the anilated compound 14. Insertion and elimination along with regeneration of catalyst results in cyclized product $\mathbf{1}$.

higher level of activation with $40 \mathrm{~min}$ of UV light radiation. It is noticed that $\mathbf{3}$ and $\mathbf{4}$ are highly photoactive against $B$. subtilis. However, $\mathbf{1}$ is most active photo-bioactive compared to all other compounds. Interestingly, the same compound $(\mathbf{1}, 15 \mu \mathrm{M})$ is inactive under dark condition (table 1). From the zone value, it is observed that $\mathbf{2}$ and $\mathbf{5}$ are lesser effective in comparison to other compounds within the specified concentration range.

3.2b DNA binding study: The high photoactive nature of compound $\mathbf{1}$ is selected for further evaluation of photo-DNA binding and DNA photo cleavage analysis. Absorption spectra of $\mathbf{1}$ with increasing amounts of DNA in $5 \mathrm{mM}$ Tris and $50 \mathrm{mM} \mathrm{NaCl}(\mathrm{pH}$ 7.2) buffer are shown in figure 1. Binding strength of compound 1 to CT-DNA is accompanied by variation in UV-vis absorption wavelength. It shows a significant hypochromic effect which is accompanied by the appearance of isosbestic points around 367 and $372 \mathrm{~nm}$ with increasing DNA concentration. Titration spectra illustrates that compound $\mathbf{1}$ has a very strong interaction with CT-DNA double helix under UV light irradiation.

3.2c Photoactivated cleavage of pBR 322 DNA: Figure 2 illustrates the photocleave ability of compound 1 on pBR322 DNA under irradiation at UV light $(\lambda=$ $365 \mathrm{~nm}$ ). In figure 2, lane 1 has expressed the presence of Form I of pBR322 DNA in the absence of compound 1 as control. Addition of $2 \mu \mathrm{M}$ concentration of compound 1 results in the formation of nicked circular DNA (Form II) in addition to Form I of pBR322 DNA

Table 1. Preliminary screening of indoloquinolines (1) to (4) and quinolino-1,8-naphthyridine (5) compounds as photoinduced antimicrobial photosensitizing agents.

\begin{tabular}{|c|c|c|c|c|c|c|}
\hline \multirow[b]{2}{*}{ Compound } & \multicolumn{2}{|c|}{$\begin{array}{l}\text { Control (dark condition) } \\
\text { Zone inhibition }(\mathrm{mm})\end{array}$} & \multicolumn{4}{|c|}{ Test Zone inhibition (mm) } \\
\hline & $5 \mu \mathrm{Mol}$ & $10 \mu \mathrm{Mol}$ & $5 \mu \mathrm{Mol}^{*}$ & $5 \mu \mathrm{Mol}^{* *}$ & $10 \mu \mathrm{Mol}^{*}$ & $10 \mu \mathrm{Mol}^{* *}$ \\
\hline DMF & - & - & - & - & - & - \\
\hline Xanthotoxin & 6 & 8 & 10 & 12 & 11 & 18 \\
\hline 1 & 2 & 2 & 9 & 14 & 12 & 25 \\
\hline 2 & 3 & 4 & 4 & 7 & 5 & 8 \\
\hline 3 & 3 & 4 & 6 & 7 & 6 & 11 \\
\hline 4 & 4 & 4 & 6 & 9 & 7 & 14 \\
\hline 5 & 3 & 3 & 4 & 6 & 4 & 9 \\
\hline
\end{tabular}

*Time of radiation is $20 \mathrm{~min}$.

*Time of radiation is $40 \mathrm{~min}$. 


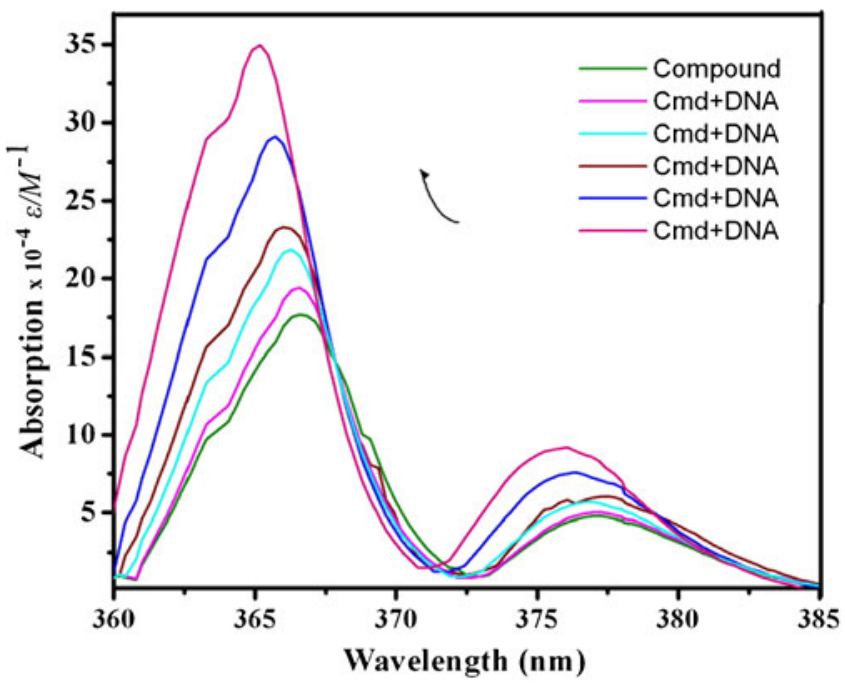

Figure 1. Titration spectra of compound $1(10 \mu \mathrm{M})$ in Tris$\mathrm{HCl}$ buffer with increasing concentration of CT-DNA base pairs: bottom curve $(0.0 \mu \mathrm{M})$ to top curve $(0.2 \mu \mathrm{M})$ was recorded in quartz cells ( $1 \mathrm{~cm}$ path length) by a UV-visible spectrophotometer at room temperature.

(lane 2). However, on further increase in concentration of compound 1 in the lanes 2 to 5, the amount of Form I of pBR322 DNA is reduced gradually and the amount of nicked circular DNA (Form II) increases remarkably. At $6 \mu \mathrm{M}$ concentration of compound $\mathbf{1}$, pBR322 DNA is completely converted from Form I to Form II indicating the DNA photocleave efficiency of compound 1. More interestingly, compound $\mathbf{1}$ can also efficiently damage DNA under irradiation at visible light. As shown in figure 3 , after irradiation at visible light $(\lambda=450 \mathrm{~nm})$ for $60 \mathrm{~min}$, the compound completely cleavages DNA at $10 \mu \mathrm{M}$. This may be attributed to the longer life time of compound $\mathbf{1}$ in an excited state and also have afforded the longer life time to exchange energy with molecular oxygen of the air, thus generating more reactive oxygen species (ROS).

To establish the reactive species responsible for the photoactivated cleavage of the plasmid, further

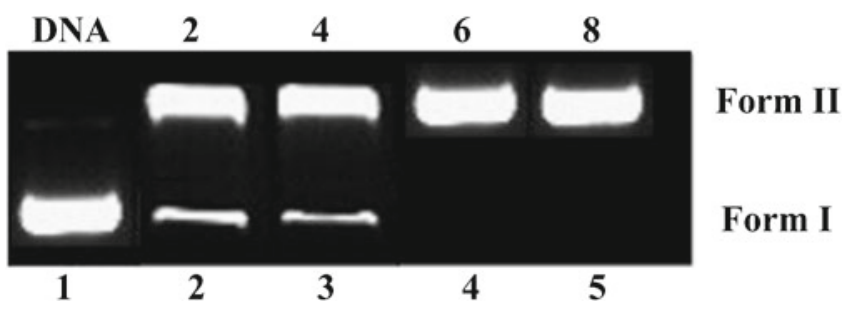

Figure 2. Photoactivated cleavage of pBR 322 in the presence of compound 1 after irradiation at $365 \mathrm{~nm}$ for $45 \mathrm{~min}$. Lane 1, DNA alone; Lanes 2-5, in different concentrations of compound: (2) 2 ; (3) 4; (4) 6; (5) $8 \mu \mathrm{M}$.

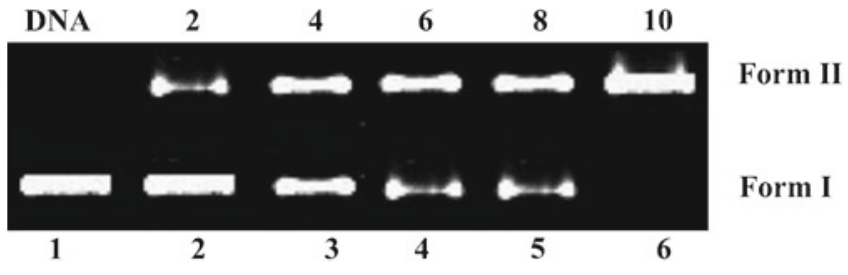

Figure 3. Photoactivated cleavage of pBR 322 in the presence of compound 1 after irradiation at $450 \mathrm{~nm}$ for $60 \mathrm{~min}$. Lane1, DNA alone; Lanes 2-6, in different concentrations of compound: (2) 2; (3) 4; (4) 6; (5) 8; (6) $10 \mu \mathrm{M}$.

investigation is conducted under the influence of different potentially inhibiting agents. Figure 4 illustrates typical results, cleavage of the plasmid is not inhibited in the presence of hydroxyl radical $\left(\mathrm{OH}^{*}\right)$ scavengers such as mannitol (lane 5) and ethanol (lane 6), indicating that hydroxyl radical $\left(\mathrm{OH}^{\bullet}\right)$ is not likely to be the cleaving agent. In the presence of the superoxide anion radical $\left(\mathrm{O}_{2}^{--}\right)$scavenger, superoxide dismutase (SOD) (lane 7), no inhibition is observed, which indicates that $\mathrm{O}_{2}^{\circ-}$ may also not be the reactive species. However, addition of the single oxygen $\left({ }^{1} \mathrm{O}_{2}\right)$ quencher histidine (lane 3) and $\mathrm{NaN}_{3}$ (lane 4) significantly inhibits the photocleavage activity of the compound 1, suggesting that ${ }^{1} \mathrm{O}_{2}$ is likely to be the reactive species responsible for the cleavage reaction. Quinoline and 1,8-naphthridine derivatives have also been reported to involve an ${ }^{1} \mathrm{O}_{2}$-based mechanism. ${ }^{33}$

\subsection{Theoretical study}

Literature studies reveal that there might be a relationship between photosensitizing activity and well charge distributed co-planarity of the molecule since the latter had induced non-covalent intercalative binding ${ }^{34}$ with DNA helix. Mallick and Chattopadhyay ${ }^{9}$ studied the

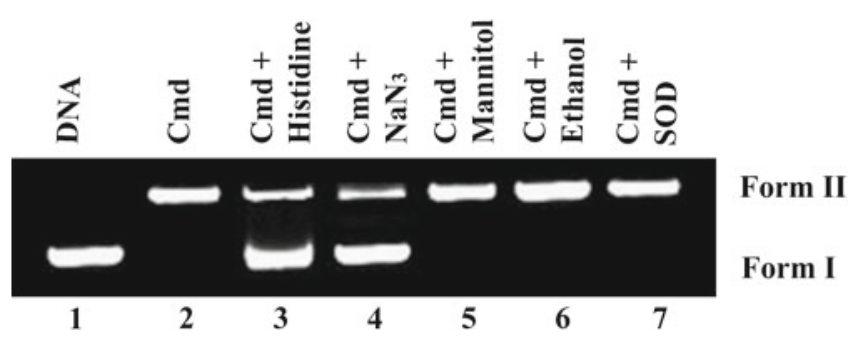

Figure 4. Photoactivated cleavage of pBR322 DNA in the presence of compound $\mathbf{1}$ and different inhibitors after irradiation at $365 \mathrm{~nm}$ for $45 \mathrm{~min}$, Lane 1, DNA control; Lane 2, no inhibitor (compound $1=8 \mu \mathrm{M}$ ); Lanes 3-7: (3) Compound $1+$ histidine $(15 \mathrm{mM})$, (4) Compound $1+\mathrm{NaN}_{3}(15 \mathrm{mM})$, (5) Compound $\mathbf{1}+$ mannitol (15 mM), (6) Compound $\mathbf{1}+$ ethanol (15 mM), (7) Compound $1+$ SOD (100 unit). 
mechanism of steady-state photophysics of heteroaromatic systems and exploited the nature of charge distribution around the microenvironment of the molecule during UV-visible irradiation. Accordingly, it can be concluded that more resonance forms and micropolarity around the probe could decide the probe-biomolecule photobinding efficiency.

Theoretical molecular modelling studies have been proved to be one of the basic tools for understanding molecular configuration in the three-dimensional space and also provide knowledge about the charge distribution within the molecular system. ${ }^{35}$ Hence, theoretical molecular modelling studies for the five compounds $\mathbf{1}$ to $\mathbf{5}$ using Chembio-Ultra3D software ${ }^{36}$ are performed. First, structural models are generated to obtain optimum structures with less energy. Figure 5 illustrates charge distribution of all the heterocyclic systems. The molecular charge distribution graph illustrates the effective photoactive nature of $\mathbf{1}$ and also the minimal activity for others ( $\mathbf{3}$ and $\mathbf{4}$ ). Finally, $\mathbf{1}$ seems to be a good candidate for photo-bioactivity.

\section{Conclusion}

Here, we have reported the synthesis of indolo and naphtheridine fused quinoline derivatives ( 1 to $\mathbf{5})$ through the elegant synthetic roots using potential quinoline intermediate systems 8,10 and 13. An examination by in vitro photoinduced antibacterial activity of the synthesized compounds ( $\mathbf{1}$ to $\mathbf{5}$ ) against $B$. subtilis is performed and specific high photo-bioactivity in $\mathbf{1}$ is observed. Based on the results, $\mathbf{1}$ is selected for preliminary photo-DNA binding and DNA photo cleavage analysis. In addition, a theoretical study of the synthesized compounds using Chem Bio-Ultra software is

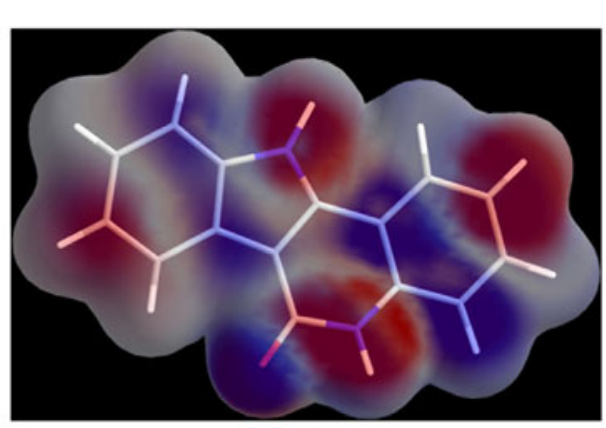

(a)

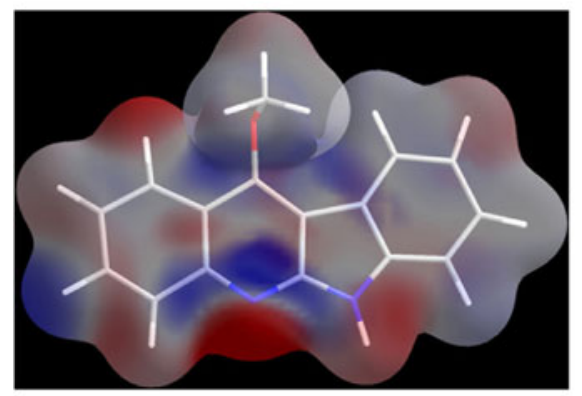

(c)

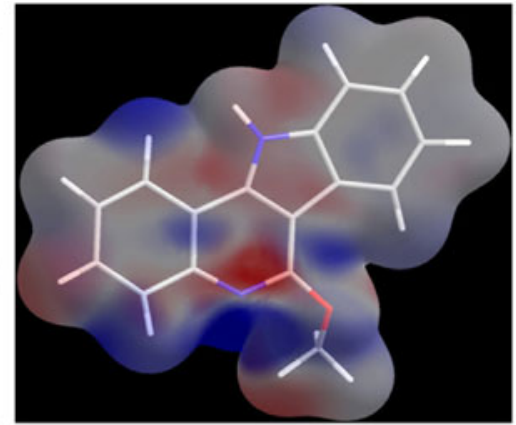

(b)

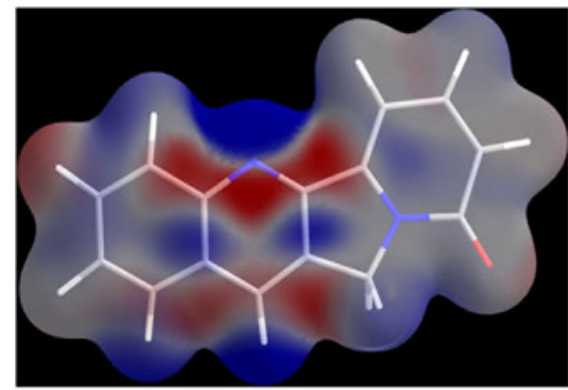

(d)

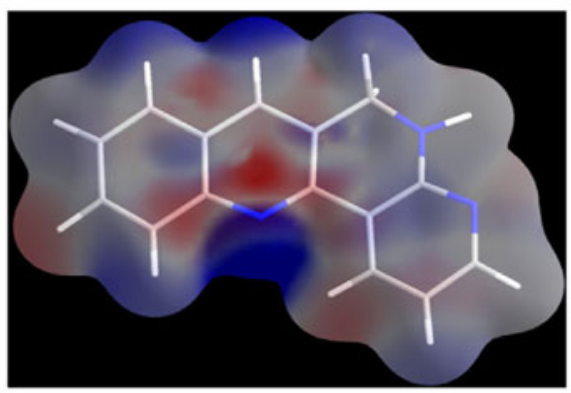

(e)

Figure 5. Chembio3D Ultra-11 model software stimulated energy minimized structure with molecular charge distribution of compounds 1 (a), 2 (b), 3 (c), 4 (d) and $\mathbf{5}(\mathbf{e})$. 


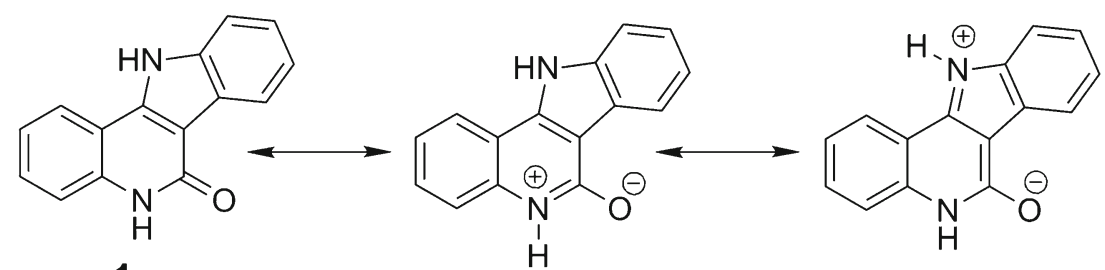

1

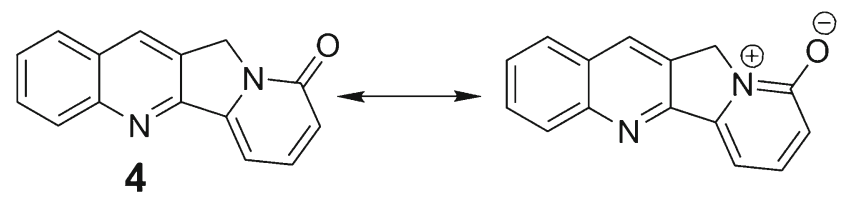

Scheme 9. Possible zwitter ion forms of photo bioactive compounds $\mathbf{1}$ and 4 . It explains the possible charge distribution within the molecular system.

also carried out to reason out the photo-bioactivity of the synthesized compounds ( $\mathbf{1}$ to $\mathbf{5}$ ). Observed conclusions of the analysis are summarized below.

- High photo-bioactivity of $\mathbf{1}$ and $\mathbf{4}$ has dictated biodistribution of the drugs within the microbial environment, which is instigated by the resonance forms of structures, i.e, zwitter ion (scheme 9). Arvizo et $a l^{37}$ reported that the resonance, i.e., charge distribution within the molecule is a key determinant of interactions of biological and synthetic materials within biosystems. It plays a quantified role in pharmacokinetics, tumour uptake and biodistribution. ${ }^{37,38}$

- Within the structural isomers (2 and 3), specific photo-bioactivity of $\mathbf{3}$ reveals the bio-activation of electronegative functional group present at the fourth position of quinoline ring (3), which is based on a similar view reported by Rothe and Jacobus. ${ }^{8}$ Hence, a detailed substitutional bioanalysis of specific heterocyclic core is always essential during drug discovery that prepares libraries for future endowers.

- Unsubstituted quinoline-1,8-naphtheridine system (5) could not induce any photo-bioactivity in the specified concentration range. Theoretical charge density map can also reveal that the molecule has very low effective charge distribution. This micropolarity may sustain its attraction towards the biomolecular systems thereby reducing photo-bioactivity. However, the observed activity results of indoloquinoline derivatives ( $\mathbf{1}$ to $\mathbf{4})$ suggest that activity study of different functional substituted quinoline1,8-naphtheridine (5) derivatives is necessary to signify the role of quinoline core in the use of photodynamic antimicrobial chemotherapy (PACT).

These results offer new possibilities for further improvements in the photo-antibacterial performance of indoloquinoline derivatives. Although this initial study can involve only a limited number of compounds, it has provided substitution-activity relationships that are worth studying further. A number of new photoantibacterial compounds are needed over the coming years, so it is important to pursue multiple strategies for drug discovery.

\section{Supplementary information}

The electronic supporting information can be seen in www.ias.ac.in/chemsci.

\section{Acknowledgements}

One of the authors (MM) thanks the Department of Science and Technology (DST), New Delhi for the award of fast track young scientist (Ref No: CS-163 dated 01.03.2012 for the years 2012-2015). We are thankful to analytical instrumentation support from the NMR Research Centre, Indian Institute of Science, Bangalore, India. We also thank Dr. C K Venil and Mis. K Raj Kokila, Department of Environmental Science, Bharathiar University, India, for help in photobiological studies.

\section{References}

1. (a) Zhang Z, Wang S, Wan S, Ren S, Li W and Jiang T 2009 Carbohydr. Res. 344 291; (b) Hostyn S, Maes B U W, Pieters L, Lemiere G L F, Matyus P, Hajos G and Dommisse R A 2005 Tetrahedron 611571

2. (a) Albert I D L, Marks T J and Ratner M A 1998 J. Am. Chem. Soc. 120 11174; (b) Leontie L, Danac R, Druta I, Carlescu A and Rusu G I 2010 Synth. Metals 160 1273; (c) Osuna R M, Ferrón C C, Vercelli B, Hernández V, Zotti G and Navarrete J T L 2010 Port. Electrochim. Acta. 2863

3. (a) Kim M H, Jin J, Lee C J, Kim N and Park K H 2002 Bull. Korean Chem. Soc. 23 964; (b) Okabe H 1981 Appl. Optics 204054 
4. Malathi M, Mohan P S, Butcher R J and Venil C K 2009 Can. J. Chem. 871692

5. Yang P, Yang Q, Qian X, Tong L and Li X 2006 J. Photochem. Photobiol. B: Biol. 84221

6. Pan H C, Liang F-P, Mao C-J, Zhu J-J and Chen H-Y 2007 J. Phys. Chem. B111 5767

7. Fels G 1968 J. Med. Chem. 11887

8. Rothe W E and Jacobus D P 1968 J. Med. Chem. 11366

9. Mallick A and Chattopadhyay N 2005 Photochem. Photobiol. B81 419

10. Miert S V, Hostyn S, Maes B U W, Cimanga K, Brun R, Kaiser M, Matyus P, Dommisse R, Lemiere G, Vlietinck A and Pieters L 2005 J. Nat. Prod. 68674

11. Sayed I E, Veken P V, Steert K, Dhooghe L, Hostyn S, Baelen G V, Lemire G, Maes B U W, Cos P, Maes L, Joossens J, Haemers A, Pieters L and Augustyns K 2009 J. Med. Chem. 522979

12. Paulo A, Gomes E T, Steele J, Warhurst D C and Houghton P J 2000 Planta Med. 6630

13. Herbal G 2003 J. Am. Bot. Council. 6054

14. Molina A, Vaquero J J, Navio J L G, Builla J A, Terasa B P, Gago F, Rodrigo M M and Ballesteros M 1996 J. Org. Chem. 615587

15. Shahabuddin M S, Gopal M and Raghavan S C 2007 J. Cancer Mol. 3139

16. Armitage B 1998 Chem. Rev. 981171

17. Van Henegouwen B 1997 In Advances in drug research, (eds) B Testa and U Mayer (New York Academic Press) p. 79

18. Bonnett R 1995 Chem. Soc. Rev. 2419

19. Taylor P W, Stapleton P D and Luzio J P 2002 Drug Discov. Today 71086

20. (a) Wainwright M 1998 J. Antimicrob. Chemother. 42 13; (b) Hamblin M R and Hasan T 2004 Photochem. Photobiol. Sci. 3436

21. (a) Ochsner M 1997 J. Photochem. Photobiol., B: Biol. 39 1; (b) DeRosa M C, Crutchley R J 2002 Coord. Chem. Rev. 233

22. Yamakoshi Y, Sueyoshi S, Fukuhara K and Miyata N 1998 J. Am. Chem. Soc. 12012363

23. (a) Merchat M, Bertoloni G, Giacomini P, Villanueva A and Jori G 1996 J. Photochem. Photobiol. B: Biol. 32 153; (b) Reddi E, Ceccon M, Valduga G, Jori G, Bommer J C, Elisei F, Latterini L and Mazzucato U 2002 Photochem. Photobiol. 75 462; (c) Spesia M B, Lazzeri D, Pascual L, Rovera M and Durantini E N 2005 FEMS Immunol. Med. Microbiol. 44 289; (d) Minnock A, Vernon D I, Schofield J, Griffiths J, Parish J H and
Brown S B 1996 J. Photochem. Photobiol. B: Biol. 32 159; (e) Segalla A, Borsarelli C D, Braslavsky S E, Spikes J D, Roncucci G, Dei D, Chiti G, Jori G and Reddi E 2002 Photochem. Photobiol. Sci. 1 641; (f) Dupouy E A, Lazzeri D and Durantini E N 2004 Photochem. Photobiol. Sci. 3 992; (g) Scalise I and Durantini E N 2005 Bioorg. Med. Chem. 133037

24. Nadaraj V, Selvi S T and Sasi R 2006 ARKIVOC x 82

25. Cruickshank R, Duguid J P and Swain R H A 1968 Medicinal microbiology (London: Churchill Livingstone Limited) vol. 11, p. 899

26. Yang P, Yang Q, Qian X, Tong L and Li X 2006 J. Photochem. Photobiol. B84 221

27. Cao R, Peng W, Chen H, Ma Y, Liu X, Hou X, Guan H and Xu A 2005 Biochem. Biophys. Res. Commun. 338 1557

28. Cohn O M and Narine B 1978 Tetrahedron Lett. 232045

29. Karabelas K and Hallberg A 1988 J. Org. Chem. 534909

30. Honzawa H, Mizutani T and Shibasaki M 1999 Tetrahedron Lett. 40311

31. Gibson S E, Guillo N, Middleton R J, Thuillez A and Tozer M J 1997 J. Chem. Soc. Perkin Trans. 447

32. Nakatani K, Sando S, Yoshida K and Saito I 2001 Bioorg. Med. Chem. Lett. 11335

33. (a) Daghastanli N A, Degterev I A, Tedesco A C and Borissevitch I E 2004 Braz. J. Med. Biol. Res. 37 1873; (b) Toshima K, Okuno Y, Nakajima Y and Matsumura S 2002 Bioorg. Med. Chem. Lett. 12 671; (c) Viola G, Salvador A, Vedaldi D, Fortunato E, Disaro S, Basso G and Queiroz M J R P 2005 J. Photochem. Photobiol. B82 105

34. Mei H Y and Barton J K 1988 J. Proc. Natl. Acad. Sci. USA 851339

35. (a) Espinosa E, Lecomte C, Ghermani N E, Devemy J, Rohmer M M, Bernard M and Molins E 1996 J. Am. Chem. Soc. 118 2501; (b) Galabov B and Parvanova P B 2000 J. Mol. Struct. 55093

36. (a) Farag N A H 2008 Euro. J. Med. Chem. xx 18; (b) Pedersen M M, Chukwujekwu J C, Lategan C A, Staden J V and Smith P J, Staerk D 2009 Phytochemistry 70 601; (c) Yuan S C, Sun Q, Lei T, Du B, Li Y F and Pei J 2009 Tetrahedron $\mathbf{6 5} 4165$

37. Arvizol R R, Miranda O R, Moyano D F, Walden C Y, Giri K, Bhattacharya R, Robertson J D, Rotello V M, Reid J M and Mukherjee P 2011 Plos One 6 e24374

38. Gwak H-S, Choi J-S and Choi H-K 2005 Int. J. Pharma. 297156 